IZA DP No. 8356

Do Preferences Impact Behavior and Wellbeing? A Panel Study of Preferred and Actual Working Time 2001-2008/09

Jens Bonke

Marie Louise Schultz-Nielsen

July 2014 


\title{
Do Preferences Impact Behavior and Wellbeing? A Panel Study of Preferred and Actual Working Time 2001-2008/09
}

\author{
Jens Bonke \\ Rockwool Foundation Research Unit \\ Marie Louise Schultz-Nielsen \\ Rockwool Foundation Research Unit \\ and IZA \\ Discussion Paper No. 8356 \\ July 2014 \\ IZA \\ P.O. Box 7240 \\ 53072 Bonn \\ Germany \\ Phone: +49-228-3894-0 \\ Fax: +49-228-3894-180 \\ E-mail: iza@iza.org
}

\begin{abstract}
Any opinions expressed here are those of the author(s) and not those of IZA. Research published in this series may include views on policy, but the institute itself takes no institutional policy positions. The IZA research network is committed to the IZA Guiding Principles of Research Integrity.

The Institute for the Study of Labor (IZA) in Bonn is a local and virtual international research center and a place of communication between science, politics and business. IZA is an independent nonprofit organization supported by Deutsche Post Foundation. The center is associated with the University of Bonn and offers a stimulating research environment through its international network, workshops and conferences, data service, project support, research visits and doctoral program. IZA engages in (i) original and internationally competitive research in all fields of labor economics, (ii) development of policy concepts, and (iii) dissemination of research results and concepts to the interested public.
\end{abstract}

IZA Discussion Papers often represent preliminary work and are circulated to encourage discussion. Citation of such a paper should account for its provisional character. A revised version may be available directly from the author. 
IZA Discussion Paper No. 8356

July 2014

\title{
ABSTRACT
}

\section{Do Preferences Impact Behavior and Wellbeing? A Panel Study of Preferred and Actual Working Time 2001-2008/09}

\begin{abstract}
Various European studies show that the majority of those employed wish to work fewer hours than they actually do. The question addressed here is whether imbalanced working hours working hour tensions - influence changes in behavior: do preferences transmit into reality? Based on a Danish longitudinal time-use study, we find that more Danes prefer shorter working hours over longer working hours, which is in contrast to the Americans. Moreover, not only do the vast majority of overworked Danes adjust their working hours, those who are underworked also do so within a decade. Factors behind these changes are analyzed and means to ensure an optimization of time- and money-related wellbeing are discussed.
\end{abstract}

JEL Classification: J22

Keywords: labor supply, working hours

Corresponding author:

Jens Bonke

Rockwool Foundation Research Unit

Sølvgade 10, 2.tv.

DK-1307 Copenhagen $\mathrm{K}$

Denmark

E-mail: jb@rff.dk 


\section{Introduction}

The number of hours worked in society is important to meet the domestic and foreign demand for goods and services, while the number of individuals’ working hours, relatively to the preferred number of working hours - the work tension - is important for the population's wellbeing. For the same reasons, the question about working time is often on the political agenda and is a central theme in negotiations between unions and employer organizations, not to mention everyday conversations in the population. Hence, it is central to know whether Danes are working their preferred number of weekly hours or whether there is an imbalance between their actual behavior and their preferred behavior, which would imply that the distribution of work and leisure time is not optimal. If there is a negative working tension - preferred working hours are lower than actual working hours - a possible implication is a productivity loss due to being overworked. Conversely, a positive working tension implies productivity gains due to being underworked and a possible motivation for advancement and a desire for high incomes. However, positive working tension also points to a potential production loss as the available work force is not being fully used. So irrespective of whether the tension is negative or positive, it is an expression of a societal welfare loss because the allocation of time differs from the working time preferences in the population.

Besides preferences for working hours, labor market constraints can also play a role in determining actual working hours. The supply of working hours is not continuous: it is often offered in full-time, part-time etc. categories due to regulations and negotiations between unions and employer organizations. Hence the restrictions on working hours within the job are also important. Moreover, the preferences for working hours rely on the existence of working time sovereignty and the determination and reliability of trustworthiness of preferences as declared by those employed on the labor market.

To investigate the study question, all employed respondents in the Danish Time-Use Panel (DTUP) were asked how many hours they actually work, whether they are content with this number of working hours and, if not, whether they want to work more or less. They were also asked how many hours more/less they would like to work given that 
changed working hours would increase/decrease their income accordingly. By asking these questions in the 2001-wave and again the 2008/09-wave, we can show whether preferences are stable over time and/or in accordance with the actual number of working hours or the working hours later implemented.

\section{Literature}

There has been extensive research on labor supply, both in relation to the decision to work and the number of hours worked, whereas the underlying preferences for working hours have received less attention, despite work tensions - the difference between preferred and actual working hours - being widespread and important for individual welfare and society in general, see Jacobs \& Gerson (2004) for the US and Reynolds (2004) for many other countries.

At the micro level, investigations of work tensions have often focused on sociological questions, such as the work-family balance issue, with reduced working hours seen as a tool for improving the quality of child families' everyday life and for resolving the socalled overwork problem (Schor, 1991; Townsend, 2001; Clarkberg \& Moen, 2001; Jacobs \& Gerson, 2004). The Hakim's (2000) preference theory of work-lifestyle choices is notable as it distinguishes between adaptive preferences varying over the lifecourse, and which are most commonly found among women, and work-centered preferences with little variation between different life-course stages, most often represented by men. The implication is that it is more difficult for men with adaptive preferences than for women with similar preferences to meet their desired working time. Wanrooy's (2005) findings for Australia support this theory, although she notes that external factors, such as childcare institutions etc., are not an integrated part of the theory.

Within the economic literature, work tensions are mostly seen as market failures, where the question is why ordinary labor supply models assuming free choice over hours worked, selecting the desired utility-maximizing outcome at a given wage are not applicable to all employees, see e.g. Steward \& Swaffield (1997). Further, the impact of 
income taxes on labor supply has been used to explain the existence of work tensions on the labor market (Klevmarken, 2005).

For both perspectives the question is what determines people's work tensions, and how it could vary between population groups. Mertz (2002) shows how preferences for working hours and desired work time differ between German freelancers, self-employed individuals and dependent employees. Further, the time-use on a household level, including household size, number of children and household income, has a central impact on women's work preferences but not on men's. However, education and work experience are found to have no impact in this study based on GSOEP (1985-1994).

If there is a negative working tension - preferred working hours are lower than actual working hours - a possible implication is the feeling of being overworked and a consequent productivity loss, while a positive working tension can imply productivity gains resulting from a possible motivation for advancement and a desire for high incomes (Reynolds \& Aletraris, 2004). Working hour mismatches may also imply lower levels of psychological and physical wellbeing and within family problems, either because of not having sufficient time or because of financial problems. Under all circumstances, negative or positive work tensions are key candidates for individuals’ welfare losses.

Labor market constraints are also central in determining actual working hours. The supply of working hours is not continuous as it is often offered in full-time, part time etc. categories due to regulations and negotiations between unions and employer organizations, albeit Steward \& Swaffield (1997) found that there was no indication of British unions rationing union workers to work fewer hours than comparable non-union workers in the beginning of the 1990s.

Moreover, job insecurity and the lack of job opportunities enable employers to supply working time not matching the demand for that time because minimum hour constraints are an increasing function of unemployment rates/risks (Steward \& Swaffield, 1997). Hence hour constraints are found to be significant determinants of British employees leaving the labor market and within- and between-employer mobility using BHPS 
(Böheim \& Tayler, 2004). This also holds for Americans, indicating that the variance of the change in hours worked is greater for job movers than for those remaining in the same job. The restrictions on working hours within the job are therefore also important. Moreover, the preferences for working hours rely on the existence of working time sovereignty and the determination and trustworthiness of preferences in general.

At the macro level, policies on working hours seem to vary according to the economic growth condition in society. In periods with high unemployment rates, the focus has often been on lowering the number of weekly working hours for new jobs, examples are Germany, France and Denmark in the 1980s, while in periods of prosperity and/or demographic changes with more elderly people, incentives aimed at delaying the retirement age and increasing the labor supply in general have been on the political agenda. Here the question is how many hours, calculated in full-time workers, the work tension amounted to in 2001 and 2008/09.

This paper aims to address these questions by investigating changes in work tensions between 2001 and 2008/09 and to what extent these changes can be explained by changes in working hours over the same period, or in other words: Are preferences for working hours revealed by changing the working hours in accordance with these preferences over a 7-8-year period?

\section{Data}

We use data from the Danish Time-Use Panel Survey 2001-2008/09 (DTUP), where the 2001- and the 2008/09 waves were both drawn randomly for the two years from administrative registers of the whole population held by Statistics Denmark. A unique identifier enabled DTUP to be merged with administrative register data for the whole Danish population. The combination of survey and administrative register data allowed us to include register information on the respondents in DTUP and to test for sample selection against the whole population. In the selected samples of men and women, those who are unemployed and those who are immigrants are underrepresented. 
Hence, we have an imbalanced panel for pooled cross-section estimations and a balanced panel for fixed effect estimations, the latter panel weighted to represent the 2008/09 adult population in Denmark. For the pooled sample, we have 4828 men and 5153 women, while the balanced sample consists of 1247 men and 1517 women. Because the age distribution goes from 18 to 74 years most employed people in the 2001-wave can also be found in the 2008/09-wave. For both waves respondents first attended an interview, which elicited basic information on, e.g., family relations, socioeconomic status, educational level, and average number of working hours. Respondents were then asked to complete two time-use diaries for each year, and if respondents were aged between 18 and 74 years and had a spouse or cohabiting partner, the spouse/partner was also asked to complete two time diaries for the same days.

In accordance with the international standard for questions about working hour tensions, for example, the International Social Survey Program; the German Socio-Economic Panel (GSOP); the British Household Panel Survey; Household, Income and Labour Dynamics in Australia (HILDA); the Danish Time-Use Surveys from 2001 (DTUS-01) and 2008/09 (DTUC-08) - and therefore in the Danish Time-Use Panel Study (DTUP) all ask whether the individual wants to work more hours and earn more or work fewer hours and earn less than he/she actually does, or whether he/she is satisfied with the number of working hours. The Danish Time-Use surveys also enquired about the number of additional or reduced hours wanted if the individual was not satisfied with the actual number of working hours. Because the Danish Time-Use surveys the DTUS64, DTUS-75 and DTUS-87 did not condition on earnings, i.e. working more or fewer hours was considered a free good, the share of workers preferring fewer hours was nearly double that of later surveys. Also to be considered is that the US investigations of work tensions show different results depending on the questions used. Hence, SousaPoza \& Henneberger (2002) using the International Social Survey Program (SSP) with the earnings compensation formulation find that the majority of work imbalanced employees in the US are underemployed and wish to work more, while Bond et al. (1998), see Otterbach (2010), using National Survey of Changing Work Force (NSCW), find that a majority of work imbalanced employees wish to work less. This calls for awareness of the exact formulation of the tension question, or as Otterbach (2010) 
states, “... the questions’ exact wording may be strongly related to contradictory research findings and the hypothetical questions they raise” (p. 148).

The DTUS and the Danish Labor Market Commission's (Arbejdsmarkedskommissionen) investigations of working hour tensions show very similar results regarding the number of employees wanting to work more versus fewer hours than they actually do. However, the latter study did not explicitly condition on earnings but instead mentioned that higher income could be an incentive to work more hours and that the earnings for the last, marginal hours were considered too low to compensate for the effort involved.

Labor Force Surveys (LFS) conducted in most European countries include information about employees and self-employed individuals’ number of weekly working hours and their desire to work more or fewer hours than they actually do with economic compensation involved. However, although the respondents are interviewed three consecutive times, the interviews all occur within 9 months, which is considered too short a time to investigate preference shifts; moreover, there is no information about partners' labor market behaviors, which is why the LFS data are not used in this paper.

Here, we include employees as well as self-employed individuals, although those who are self-employed are assumed to have greater freedom to choose their labor supply. In contrast with Böheim \& Taylor (2004), we include people with secondary jobs - held by around 10 percent of the Danish labor force in 2008 (Bonke, 2012) - because a secondary job might neutralize main job work tensions, which is what we deal with in this and in most other papers.

We do not consider those who are unemployed, as does Merz (2002), because it can be reasonably assumed that they wish to work a positive number of hours, i.e., more hours than they actually do, see, for example, N. Smith et al. (1998), and because this issue is more a question of working incentives and mismatch between demand and supply of labor to the labor market. 
Information on educational background refers to the longest completed course of education registered in the administrative registers. We create a binary indicator for whether the individual had completed a further education, which includes short-course further education (less than 3 years), medium-course further education (3 to 4 years), and long-course further education (more than 4 years).

Additional control variables are age, civil status (cohabiting/married), number of children and net household income. Information on the income comes from the administrative register data and is calculated into quintiles.

\section{Empirical strategy}

Many labor supply studies exist, see, for example, Blundell \& MaCurdy (1999) and Klevmarken (2005), where wages, virtual income and different socioeconomic factors are shown to have important impacts. Here, we investigate changes in working time among those employed and how these changes can be explained by explicitly mentioned preferences for working hours given various socioeconomic characteristics. We also investigate whether work tensions - unfulfilled work preferences - are removed through actual working-hour changes, and how preferences and working-hour changes impact satisfaction with working conditions in general.

The empirical models applied first include a model for explaining how preferences are revealed in the event of changes in working hours over the period 2001-2008/09 and controlled for heterogeneity such as sex, age etc.

(1) $\Delta$ working hours ${ }^{2008-2001}=\mathrm{f}\left(\right.$ pref $^{2001}$, age, age ${ }^{2}$, sex $)$.

The next model uses changes in working hours during the period together with preferences in 2001 and structural and individual characteristics to predict the work tension/preferences in 2008.

(2) $\quad \operatorname{Pref}^{2008}=\mathrm{g}\left(\Delta\right.$ working hours ${ }^{2008-2001}$, pref $^{2001}, \Delta$ flex work, $\Delta$ sec. job, 
$\Delta$ marriage, $\Delta$ children, $\Delta$ educ., age, age ${ }^{2}$, sex)

We also investigate the impact of changes in preferences and specific working conditions, such as flexible working hours and a secondary job, on the satisfaction with working conditions in general and controlled for some socioeconomic characteristics. Hence, from the literature, see e.g. Clark (1996), we know that working hour tension contributes to working conditions, and the formalized equation is as follows

(3) $\Delta$ workconditions $^{2008-2001}=\mathrm{h}\left(\Delta\right.$ work tensions ${ }^{2008-2001}, \Delta$ flex work, $\Delta$ sec. job, $\Delta$ marriage, $\Delta$ children, $\Delta$ educ., age, age ${ }^{2}$, sex).

Here, working conditions refer to a subjective question about satisfaction with working conditions in general, thereby becoming one of more domain satisfactions (Bonke et al., 2009).

The first model (1) uses OLS estimations of changes in working hours as the dependent variable with categories ranging from -55 to 55 , while the next model (2) uses multinomial logit-estimations with the same hours as the reference category and underand over-employment in 2001 among the explanatory variables, based on the assumption that the preferences for working more hours are correlated with the preferences for working fewer hours a week, see Böheim \& Taylor (2004) for estimating the same model for Britain. Finally, the last model (3) uses OLS estimations with satisfaction categories from -6 to 6 .

The model used for the preference estimations in (2) is also the one used when estimating the intra-personal relationship between the spouses' working times and their preferences for working more or fewer hours a week, see Table 3.

\section{Descriptives}

The period investigated here is the 2000s with 2001 as the first year and 2008/09 as the second year determined by the two available waves in the DTUP. From Figure 1 we see that 2008/09 was characterized by a low unemployment rate and a prosperous economic 
situation, which make the preferences and actual working hours less influenced by economic growth differentials, at least at the macro level. The figure also includes information for the whole 2007-2011 period, i.e. working-hour preference information was not available before that time, which indicates that preferences for working hours are correlated with the business cycle. That is, more people preferring more hours and fewer people preferring fewer hours when there is an economic crisis/high unemployment rate, as was the case immediately after the second wave of the DTUP, and, conversely, that economic growth/low unemployment rate is correlated with fewer people wanting more working hours and more people wanting more working hours, see Bonke (2013).

Figure 1

Preferences for more or less work 2007-2011

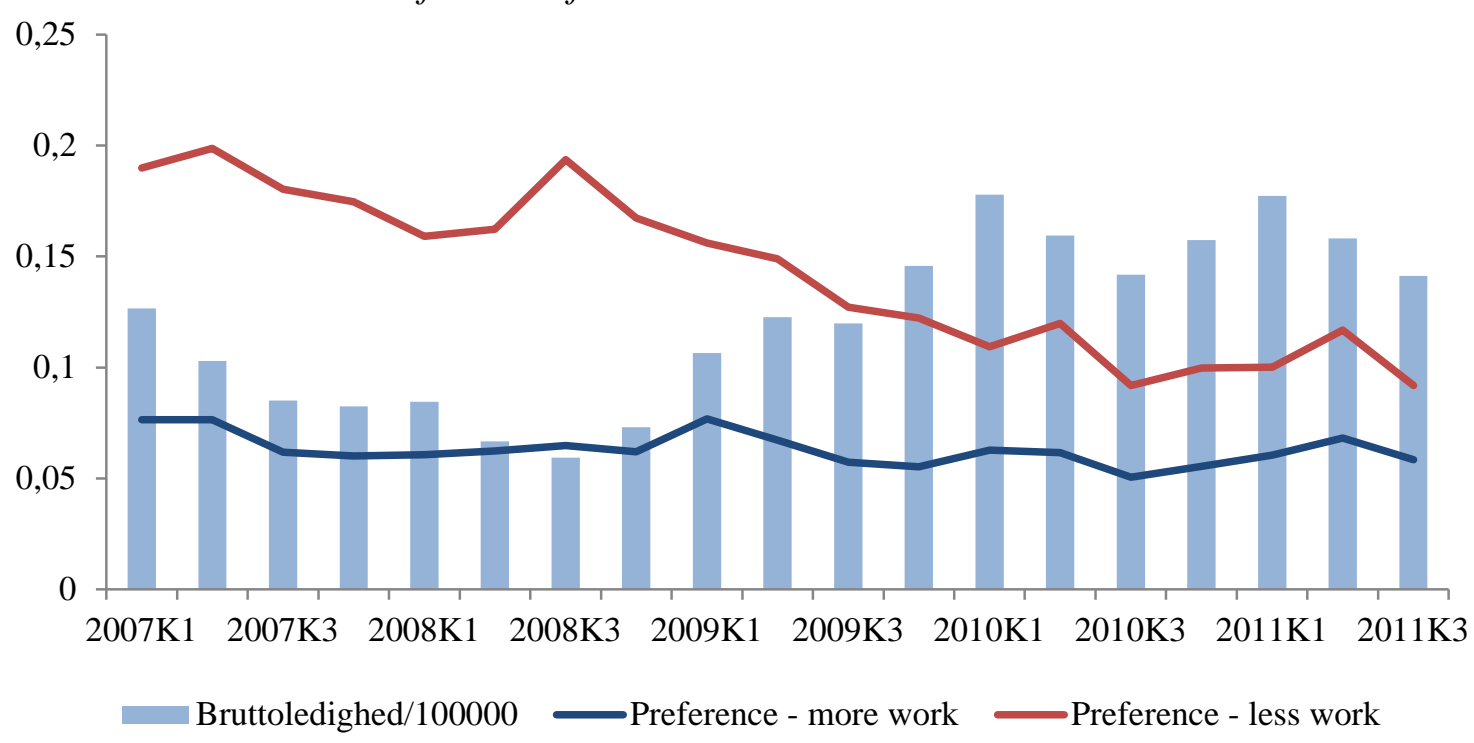

Source: Labour Force Survey, Eurostat

This relationship between unemployment rate and preferences for more or less work is also found when doing macro-level analyses including several countries for the years 1997 and 2005 (Otterbach, 2010). In countries with high unemployment rates, the proportion of workers preferring to work more hours is higher than in countries with lower unemployment rates, while the proportion of satisfied workers and workers 
preferring to work fewer hours declines with higher unemployment rates. A likely explanation is that unemployment creates more disciplined workers fearing redundancy and who, accordingly, are willing to work more hours, earning more income for future consumption. In growth periods/countries, this fear is much smaller; consequently, stating a preference for fewer hours is less risky. The opposite picture emerges for the relationship between GDP per capita and hour constraints, as the preferences for more (fewer) hours is higher (lower) in poor countries than in rich countries.

That the preferences for working time are in accordance with actual working hours - no work tension - for most people in most countries is confirmed in Table 2 for Denmark. Hence 3 out of 4 persons in employment are satisfied with their actual working hours for the year 2008/09, while only 2 out of 3 had that privilege in 2001. Among those not satisfied with their working hours, 50 percent more want to reduce the number of working hours relatively to those wanting to increase these hours. In 2001, 21 percent wanted to work more hours; in 2008/09 it was 16 percent (Arbejdsmarkedskommissionen: 20 pct.), whereas the percentage of people wanting to work more hours was only 11 percent for the two years (Arbejdsmarkedskommissionen 6 pct.).

A comparison of 21 countries based on the International Social Survey Program, 1997 and 2005 (Otterbach, 2010) shows that the large majority of workers do not face hour constraints, with Denmark, Norway and Switzerland in the top end, and that the majority of the constrained, in particular US workers, prefer longer working hours - see also Reynolds (2004) about work tension in the US. The exceptions are Denmark, Switzerland and Norway where the majority of the hour constrained at that time wanted to work fewer hours and to some extent Sweden with an equal number of people with preferences for more and fewer hours. When applying the same data for 1997 only, the same picture emerges (Sousa-Poza \& Henneberger, 2002; Stier \& Lewin-Epstein, 2003).

Similarly, in 2008/09 we find that fewer Danish women than men wish to have more working hours, but more women than men wish to have fewer working hours. 
Notably, there were no changes in weekly working hours agreed upon between the unions and employers organizations in Denmark during that period, the only change was that 3 yearly holidays was gradually introduced up to 2002 and thereafter to 5 days or the sixth holiday week.

The wish to work more or fewer hours, as referred to here, means a change of at least 1 hours' work a week and that the income changes in line with the change in hours, i.e., lower income with fewer hours and higher income with more hours worked. This implies that in 2008/09, 11 percent wanted to increase their working time by at least 1 hour and 16 percent wanted to decrease their working time by at least 1 hour.

Table 2

Weekly working hours in main occupation and the desired working hours, employed 2001 and 2008/09

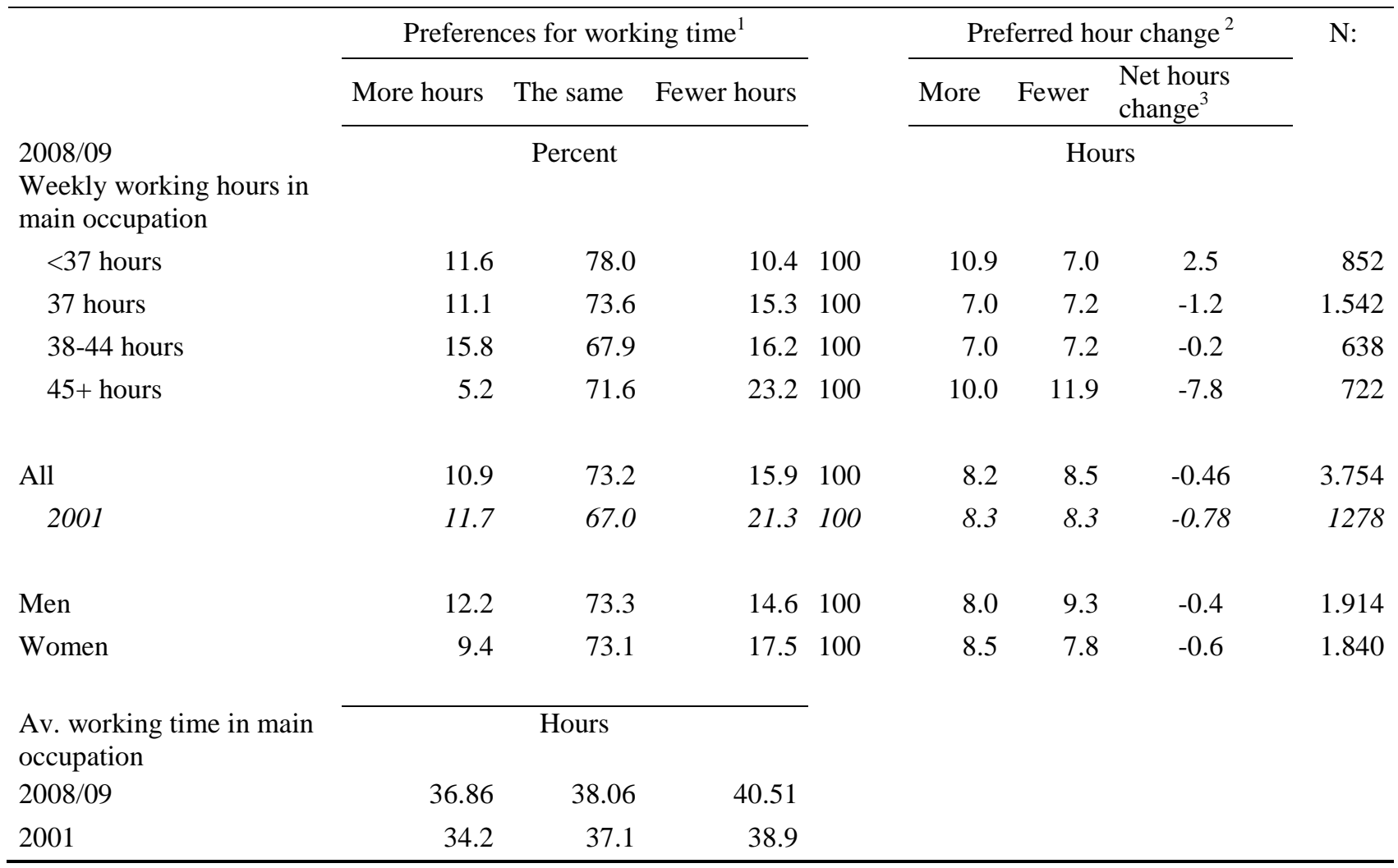

1 Q: If possible, would you then wish to work more hours and earn more or work fewer hours and earn less? Q: How many more/fewer hours would you circa like to work?

2 More and fewer hours weighted with their proportions and added together, i.e. net hours change. Source: Rockwool Foundation Research Unit 
Not surprisingly, people working many hours a week are also those who more often wish to work fewer hours, and vice versa: more people working fewer hours wish to work more hours than do those working many hours a week, see also Drago et al. (2005) for the same finding for Australia. For Danes working more than 44 hours a week, the relationship is 4:1 (23 and 5 pct.), and 1:1 (16 and 16 pct.) for those working between 38 and 44 hours a week, and nearly the same for the majority of employed people who work 37 hours a week. However, having part-time work, i.e., working fewer than 37 hours a week, means that more want to work more rather than fewer weekly hours. The same is found for the Netherlands, with a wish for a shorter working week the more a woman works, and a wish for a longer working week the fewer hours a woman works; men were not included in that analysis (Yerkes, 2004).

Because the same questions about preferred and actual weekly working hours were asked in the Danish Time-Use Survey 2001 (DTUS-01) and the Danish Time-Use and Consumption Survey 2008/9 (DTUC), and the two surveys together constitute a panel, we are able to investigate how preferences and actual working hours have changed for the same people over the 2001-08/09 period. As the Danish labor market is often considered very flexible with a high degree of mobility/job changes (Andersen, 2012), the expectation is that workers with imbalanced working times in 2001 are no longer work-time restricted in 2008/09, unless new work tensions have appeared and working time remains unchanged in 2008/09.

\section{Couples' preferences for working hours}

In the following we distinguish between husbands' and wives' and cohabiting partners' allocation of time and working hour tensions because gender roles and career patterns are supposed to vary between the two spouses of the household and because labor supply decisions are primarily made in the household context. The spouses' working hour preferences are therefore determined not only by their own actual working time, but also by that of their partners due to a desire to either synchronize or specialize their time allocations. 
Table 3

Determinants of the preference for working more or fewer weekly hours.

Employed husbands and wives - married or cohabiting. 2008/09, Multinomial regression model

\begin{tabular}{|c|c|c|c|c|}
\hline & \multicolumn{2}{|c|}{ Husbands' desire to work: } & \multicolumn{2}{|c|}{ Wives’ desire to work: } \\
\hline & More & Less & More & Less \\
\hline \multicolumn{5}{|l|}{ Own working time } \\
\hline \multirow[t]{2}{*}{$<37$ hours } & $0.801^{*}$ & 0.0714 & $0.762^{* *}$ & $-0.868 * * *$ \\
\hline & $(0.33)$ & $(0.33)$ & $(0.27)$ & $(0.18)$ \\
\hline \multirow[t]{2}{*}{$>37$ hours } & 0.0291 & $0.408^{*}$ & 0.518 & 0.227 \\
\hline & $(0.20)$ & $(0.16)$ & $(0.34)$ & $(0.19)$ \\
\hline \multicolumn{5}{|l|}{ Partners' working time } \\
\hline \multirow[t]{2}{*}{$<37$ hours } & $-0.627^{*}$ & -0.019 & -0.317 & 0.156 \\
\hline & $(0.26)$ & $(0.19)$ & $(0.48)$ & $(0.32)$ \\
\hline \multirow[t]{2}{*}{$>37$ hours } & 0.254 & 0.041 & $-0.582 *$ & -0.091 \\
\hline & $(0.21)$ & $(0.19)$ & $(0.25)$ & $(0.16)$ \\
\hline \multirow[t]{2}{*}{ Age } & 0.0845 & $0.411^{* * *}$ & 0.0132 & 0.0422 \\
\hline & $(0.08)$ & $(0.08)$ & $(0.10)$ & $(0.07)$ \\
\hline \multirow[t]{2}{*}{$\mathrm{Age}^{2}$} & $-0.0018+$ & $-0.0043^{* * *}$ & -0.0011 & -0.0003 \\
\hline & $(0.00)$ & $(0.00)$ & $(0.00)$ & $(0.00)$ \\
\hline \multirow[t]{2}{*}{1 child (no children) } & -0.252 & -0.171 & $-0.610+$ & 0.131 \\
\hline & $(0.26)$ & $(0.22)$ & $(0.33)$ & $(0.23)$ \\
\hline \multirow[t]{2}{*}{2 children } & $-0.490+$ & -0.221 & $-1.304 * * *$ & $0.598 * *$ \\
\hline & $(0.26)$ & $(0.22)$ & (0.39) & $(0.23)$ \\
\hline \multirow[t]{2}{*}{ 3+ children } & $-0.984 *$ & $-0.639 *$ & $-0.730+$ & $0.499+$ \\
\hline & $(0.41)$ & $(0.32)$ & $(0.44)$ & $(0.29)$ \\
\hline \multicolumn{5}{|l|}{ Education } \\
\hline \multirow[t]{2}{*}{ Vocational training } & 0.0125 & -0.236 & -0.522 & 0.0241 \\
\hline & $(0.26)$ & $(0.21)$ & $(0.33)$ & $(0.23)$ \\
\hline \multirow[t]{2}{*}{ Short further educ. } & -0.00166 & 0.168 & 0.197 & -0.223 \\
\hline & $(0.46)$ & $(0.33)$ & $(0.35)$ & $(0.29)$ \\
\hline \multirow[t]{2}{*}{ Medium further educ. } & $0.944 * *$ & -0.0146 & $-0.760^{*}$ & -0.0565 \\
\hline & $(0.31)$ & $(0.27)$ & $(0.36)$ & $(0.24)$ \\
\hline \multirow[t]{2}{*}{ Long further educ. } & -0.106 & 0.135 & $-1.278^{*}$ & 0.193 \\
\hline & $(0.35)$ & $(0.26)$ & $(0.52)$ & $(0.27)$ \\
\hline \multirow[t]{2}{*}{ Secondary job (no sec job) } & -0.0190 & -0.431 & $0.658+$ & -0.109 \\
\hline & $(0.31)$ & $(0.27)$ & $(0.38)$ & $(0.32)$ \\
\hline \multirow[t]{2}{*}{ Constant } & -2.231 & $-10.85 * * *$ & -0.379 & $-2.581+$ \\
\hline & $(1.46)$ & $(1.71)$ & $(1.72)$ & $(1.40)$ \\
\hline Number - more/less & 121 & 244 & 87 & 288 \\
\hline Number & \multicolumn{2}{|c|}{1474} & \multicolumn{2}{|c|}{1468} \\
\hline Log likelihood & \multicolumn{2}{|c|}{$-1004,27$} & \multicolumn{2}{|c|}{$-874,78$} \\
\hline Pseudo & \multicolumn{2}{|c|}{0,07} & \multicolumn{2}{|c|}{0,08} \\
\hline LR (chi)32 & \multicolumn{2}{|c|}{160,12} & & \\
\hline
\end{tabular}

$+p<0,1,{ }^{*} p<0,05,{ }^{* *} p<0,01,{ }^{* * *} p<0,001$ 
Note: Inclusive of a flexible working condition variable.

Source: Rockwool Foundation Research Unit

By applying multinomial regression models separately for married/cohabiting women and men wishing to work more or fewer hours than they actually do as the dependent variable and controlling for different socioeconomic factors, Table 3 shows that only for men is a high number of working hours associated with the wish to work fewer hours relatively to that of men with standard working hours, i.e., 37 hours per week. For women no such relationship is found: a smaller number of working hours is associated with a wish to work fewer hours, which is not the case for their male counterparts. However, for husbands and wives alike working part time - fewer than 37 hours per week - more wish to work more hours than husbands and wives working standard hours.

It is not only husbands' and wives' own working time that has implications for their work tensions, that of their partners also matters. Hence, if the wife has a part-time job, it is less likely that her husband wishes to work more hours than if she works the standard 37 hours a week. However, if the husband works more than the standard weekly number of hours, the wife is less likely to wish to work more hours a week. This indicates that in the first case, there seems to be some synchronization process in play, while in the second case, some specialization with a career man and a home-oriented woman characterizes the household.

Table 3 also shows that men's desire to work fewer hours - and more - increases with their age up to a given point and thereafter declines. For women there is no such relationship between their age and desire to work more or fewer hours. However, when children are involved, there is a strong impact on women's preferences for working hours, see also Drago et al. (2006) for Australia. Having the first child reduces the mother's desire to work more hours and this becomes more pronounced when the second child is born. A third child also decreases the desire to work more hours, albeit less than with the second child and little more than that implied with the first child, which is a pattern also found for German women (Mertz, 2002). This pattern is reinforced when including the desire to work fewer hours, which is more pronounced 
for mothers of two and three children than for women without children. For men with three children, the desire to work more hours is almost the same as that of their female counterparts, relatively to men and women without children. However, contrary to women, having three children implies a less pronounced desire to work fewer hours among men; moreover, having two children impacts men only half as much as it does women regarding the wish to work more hours. This shows that men with three children were more work-hour balanced in 2008/09 than were other men, and women in general.

In accordance with Sousa-Poza \& Henneberger (2002), we find that the desire to work fewer hours increases with age for men, although the lack of balance decreases when becoming older. For women no such relationship is found between age and imbalanced working hours.

Finally, the desire to work more hours is more pronounced among men with medium further education than among men without any further education, although their working times are nearly the same length. For women with medium or long further educations, the opposite appears as fewer of them want to work more hours compared with women without any education. That long further education has a different impact on men and women's working preferences is interesting. Men and women with long further educations both have longer working times than do men and women with another or no educational background (not shown in Table 3). A possible explanation for highly educated men having longer working times than their female counterparts is that these men have a career and are less responsible for family life than are highly educated women.

\section{A panel analysis of preferred and actual working hours - a harmonization process - and constraints}

The preference theory assumes that peoples’ revealed preferences represent their normative preferences understood as economic agents' true interests, and that preferences are stable over time, which means that a person will only change his/her behavior if it contributes to an optimization of available resources (Beshears et al., 
2008). Hence, the desired number of working hours, for instance, determines an individual's actual number of working hours unless his/her living arrangement and environment make such a change impossible because of different kinds of constraints.

Table 4 shows that more than half of those employed in 2001 and 2008/09 were satisfied with their working hours in both years, while 7 percent maintained the desire to work fewer hours and 2 percent to work more hours per week. The remaining 37 percent changed their working hour preferences during the period. Hence, 11 percent of those wishing to work fewer hours in 2001 were satisfied with their working hours in 2008/09, and 4 percent wishing to work more hours had become satisfied in 2008/09. Among those who were satisfied with their working hours in 2001 but not in 2008/09, nearly the same percent wanted to work fewer or more hours, i.e. 11 percent in 2008/09.

Table 4

Working hour tensions 2001 and 2008/09, and changes in working hours employed 2001-2008/09

\begin{tabular}{|c|c|c|c|c|}
\hline \multirow[t]{2}{*}{ N: 763} & \multicolumn{3}{|c|}{2001} & \multirow[b]{3}{*}{ All } \\
\hline & & Preferences & & \\
\hline 2008/09 & More hours & Same hours & Fewer hours & \\
\hline Preferences & \multicolumn{3}{|c|}{ Per cent } & \\
\hline More hours & (1.7) & 10.7 & $(0,5)$ & 12.9 \\
\hline Same hours & 4.7 & 52.1 & 11,5 & 68.3 \\
\hline Fewer hours & $(0.1)$ & 11.4 & 7.3 & 18.8 \\
\hline \multirow[t]{2}{*}{ All } & 6.5 & 74.2 & 19.3 & \multirow[t]{5}{*}{100,0} \\
\hline & & Hours & & \\
\hline Change in working hours 2001-2008/09 & 8.45 & 3.59 & 1,97 & \\
\hline Working hours 2001 & 30.44 & 35.70 & 36.15 & \\
\hline Working hours 2008/09 & 38,88 & 39.30 & 38.12 & \\
\hline
\end{tabular}

Source: DTUP, Rockwool Research Foundation Research Unit.

In Germany only every fourth (27\%) self-employed individual and employee remained satisfied with their working hours from 1985 to 1994 (Merz, 2002) relatively to 52 percent in Denmark between 2001 and 2008/09 and 72 percent in the UK in the period 1991-99 (Böheim \& taylor, 2004). In both years, the great majority wanted to work fewer hours. For Australia, the number of satisfied individuals in two consecutive years, 2001-2002, was nearly 40 percent, whereas 17-18 percent not satisfied in the first year 
became satisfied during the next year (Reynolds \& Aletratis, 2006). That only 20 percent of Germans not satisfied with their working hours in 1985 were satisfied in 1994, relative to 62 percent of the Danes changing from being unsatisfied in 2001 to satisfied in 2008/09, and that the total mover-index (proportion of people changing their preferences in the period) for Germany was 49 and 39 for Denmark in the two periods is probably due to a more rigid German labor market with a smaller labor mobility and that the year 1994 and also to some degree 1985 were both characterized by high unemployment rates contrary to the years 2001 and 2008/09, which were growth years in Denmark and in Germany.

An important question is whether under- and over-employed workers in 2001 remain unsatisfied with their working hours in 2008/09, either because the number of working hours has not changed within that period, or because such a change was not sufficiently large to satisfy their working hour preferences. Table 4 shows that those preferring more hours of work in 2001 on average worked 8.5 hours more per week in 2008/09. Correspondingly, those who wanted to work fewer hours in 2001 actually worked 2.0 hours more in 2008/09. Because working time also increased for "balanced” people, the change in working time was larger for underworked than for overworked people, compared with the development in the working hour norms during the two years under consideration.

Böheim \& Taylor (2004) showed results similar to those of this paper but for Britain during 1991-99, where the majority (nearly 40 pct.) of men as well as women working full-time and having positive tensions - under-employed - increased their working hours. The same was shown for negative tensions - over-employed - men and women decreased their working hours (nearly 40\%) between two consecutive years during 1991-1999. That said, however, more than 25 percent of the under-employed reduced and the same number of the over-employed increased their working hours during the same period, which shows that the working time preferences are not stable over time or that working hour constraints are widespread on the British labor market. 
Table 5

Preferred working hours and changes in weekly working hours employed 2001-2008/09.

\begin{tabular}{|c|c|c|c|c|c|}
\hline$N: 763$ & Pct. & $\begin{array}{c}\Delta \text { working hours } \\
\text { 2001-2008/09 }\end{array}$ & & Pct. & $\begin{array}{c}\Delta \text { working hours } \\
\text { 2001-2008/09 }\end{array}$ \\
\hline \multirow[t]{2}{*}{2001} & & Coeff. (st.err.) & 2008/09 & & Coeff. (st.err.) \\
\hline & & & Balance & 52.2 &..$(. .)^{1}$ \\
\hline \multirow[t]{3}{*}{ Balance } & 68.5 &..$(. .)^{1}$ & Under-employed & 4.7 & $-4.166+(2.231)$ \\
\hline & & & Over-employed & 11.6 & $1.453(1.491)$ \\
\hline & & & Balance & 10.8 & $4.441^{* *}(1.580)$ \\
\hline \multirow[t]{3}{*}{ Under-employed } & 12.9 & $4.627^{* *}(1.439)$ & Under-employed & $(.)$. & -- \\
\hline & & & Over-employed & (..) & -- \\
\hline & & & Balance & 11.2 & $-4.228 * *(1.511)$ \\
\hline \multirow[t]{2}{*}{ Over-employed } & 18.6 & $-2.191+(1.206)$ & Over-employed & 7.3 & $0.899(1.820)$ \\
\hline & & & Under-employed & (..) & -- \\
\hline \multicolumn{2}{|l|}{ Age (2001) } & $0.572+(0.335)$ & & & $0.441(0.336)$ \\
\hline \multicolumn{2}{|l|}{$\operatorname{Age}^{2}$} & $-0.008+(0.004)$ & & & $-0.006(0.004)$ \\
\hline Sex & & $\begin{array}{c}-3.479 * * * \\
(0.924)\end{array}$ & & & $-3.419 * * *(0.924)$ \\
\hline Constant & & $-0.669(6.575)$ & & & $1.761(6.612)$ \\
\hline Adj. $\mathrm{R}^{2}$ & & 0.044 & & & 0.050 \\
\hline
\end{tabular}

${ }^{1} \Delta$ working hours balance-balance 3.602 (0.620 ) --<20 obs.

Weighted data

Source: DTUP, Rockwool Foundation Research Unit.

We also see that for those able to fulfill their preferences of working fewer hours in 2001 and, hence, becoming satisfied with their working hours in 2008/09, they actually reduced their working time by $4 \frac{1}{4}$ hours per week in that period (Table 5).

Equivalently, for those wanting to work more hours and becoming satisfied with their working hours in 2008/09, the working time increased by $4 \frac{1}{2} 2$ hours per week in 20012008/09. A comparison with Dutch employees - not those self-employed - also shows that individuals are able to decrease their working time, providing that is the preference, even within two-year periods, i.e., 1986-1988, 1988-90 to 1996-1998 (Baaijens \& Schippers, 2007). 
Table 6

Preference shifts and working constraints - employed Multinomial logistic regression estimations.

\begin{tabular}{|c|c|c|}
\hline$N: 762$ & More work/same work 2008 & Less work/same work 2008 \\
\hline \multicolumn{3}{|c|}{ Preferences 2001: } \\
\hline More work & $.428(.414)$ & $-1.604^{* *}(0.555)$ \\
\hline Less work & $-2.233 *(1.075)$ & $1.134 * * *(0.220)$ \\
\hline \multicolumn{3}{|c|}{ Actual working hours: } \\
\hline Increased & $.235(.447)$ & $-0.580 *(0.295)$ \\
\hline Decreased & $-0.493(0.367)$ & $-0.038(0.214)$ \\
\hline \multicolumn{3}{|c|}{ Working conditions: } \\
\hline \multicolumn{3}{|c|}{ Flexible working time: } \\
\hline 2001 not 2008 & $0.136(0.548)$ & $-0.301(0.353)$ \\
\hline 2008 not 2001 & $0.826 *(0.359)$ & $-0.273(0.269)$ \\
\hline \multicolumn{3}{|l|}{ Secondary job: } \\
\hline 2001 not 2008 & $-1.109(0.794)$ & $-0.149(0.320)$ \\
\hline 2008 not 2001 & $-1.553(1.1349)$ & $-0.305(0.526)$ \\
\hline \multicolumn{3}{|l|}{ Socioeconomics: } \\
\hline$\Delta$ Marriage & $0.697+(0.372)$ & $-0.486+(0.267)$ \\
\hline$\Delta$ Children & $-1.953 * * *(0.530)$ & $0.385+(0.224)$ \\
\hline$\Delta$ Further educ. & $-0.463(0.620)$ & $-0.951(0.611)$ \\
\hline Age (2001) & $0.011(0.128)$ & $0.166+(0.087)$ \\
\hline Age $^{2}$ & $-0.001(0.002)$ & $-0.003 *(0.001)$ \\
\hline Sex & $0.153(0.324)$ & $0.129(0.199)$ \\
\hline Constant & $-1.041(2.258)$ & $-3.826+(1.688)$ \\
\hline Adj. $\mathrm{R}^{2}$ & 0.134 & 0.134 \\
\hline
\end{tabular}

An important question is how hour mismatches are created and resolved through changes in both actual and preferred hours of work, see Reynolds \& Aletraris (2006) for addressing this issue for Australia. Table 6 shows that there is no correlation between being underworked in the years 2001 and 2008/09 when taking, for example, changes in 
working hours into consideration, while being underworked in 2001 has a negative impact on the desire to work fewer hours - being overworked - in 2008/09. For those being overworked in 2001, there was a positive impact on the number of people wanting to work fewer hours and a negative impact on those wanting to work more hours in 2008/09. This indicates that for underemployed people, controlling for working hour changes implies a higher work tension balance, while this is only partially the case for those over-employed, of whom some contribute to accentuating the wish to work fewer hours and others decrease the wish to work more hours a week.

The isolated impact of working hour changes on preferences for working time is very limited as neither working more hours or working fewer hours are correlated to the desire to work more hours, and the same holds for the correlation between a decrease in working hours and the wish to work fewer hours. Further, a working hour increase implies fewer people wanting to work fewer hours when controlling for working hour preferences in 2001, possibly because of adaptive preferences integrating actual behavior into an individual's preference function.

An interesting result is that having a flexible working hour arrangement (the ability to alter either the daily starting or ending times of the work day) during 2001-08/09 is positively associated with the desire to work more hours, i.e., being underemployed, while there is no association with the desire to work fewer hours, although the latter coefficient is negative. This shows that the work schedule itself does not reduce work tensions; instead, it increases the demand for working more hours, which is opposite to findings for the US, where flexible working hours - not the change in this arrangement - increases the desire to work fewer hours (Golden \& Gebreselassie, 2007).

Relative to flexible working arrangements, the having or losing a secondary job during 20012008/09 has no impact whatsoever on work hour tensions in 2008/09. This also holds for changes of job, which, in contrast to findings by Böheim \& Tayler (2004), does not have any impact on work tension, neither does it impact any of the other coefficients (results not shown in table). 
Lastly, the models in Table 6 also include some socio-demographic characteristics showing that being married increases the desire to work more hours and decreases the desire to work fewer hours on the labor market. This is to be considered a net impact as we control for sex. Furthermore, having a child has the opposite impact to being married: having a child decreases the likelihood of wanting to work more hours and increases the desire to work fewer hours. The impact of having a child, however, is not found to be larger for men than for women, i.e. the coefficient for an interaction term is not becoming significant (not shown). Having a further education is not correlated to the desire to work either more or fewer hours a week, neither does sex impact work tension, even if we interact with being married or having children (not shown).

\section{Work hour tension and wellbeing}

An important element in satisfaction with ones working conditions is the number of hours worked, especially whether this number is in accordance with the preferences for the amount of working time per week. British data show that working hours have a significant impact on job satisfaction, motivation and retention of employees (Clark, 1996). This relationship is confirmed in Table 7, where the satisfaction with working conditions "are you satisfied with your working conditions/financial situation/amount of leisure” with 6 categories ( 1 not satisfied ... 6 very satisfied) is higher for people who are satisfied with their working time - no work tension - than for people wanting to work more hours and in particular for those wanting to work fewer hours, which holds for both 2001 and 2008.

In regressions for 2001 and 2008/09, respectively, we also find that overworked individuals, particularly women, are less satisfied with their working conditions and that underworked individuals are more satisfied (not significantly) than are people satisfied with the number of working hours worked. Moreover, having fixed working time is also associated with greater satisfaction with working conditions (not shown in tables).

Table 7 shows that the desire to work more or fewer hours may be due to economic reasons inasmuch as people with a desire to work more hours are less satisfied with their financial situation than are people in working hour balance; this is even more pronounced when comparing with people wanting to work fewer hours. Lastly, and more obvious, there is a correlation between working tension and the satisfaction with 
the amount of leisure time as the two time uses are obvious substitutes whenever we include or exclude household work and sleep in the comparison (Bonke et al., 2009). Hence, the desire to work fewer hours is related to a much smaller degree of satisfaction with leisure time than is the desire to work the same or more hours a week.

Table 7

Satisfaction within different domains, employed 2001 and 2008/09

\begin{tabular}{|c|c|c|c|c|}
\hline \multicolumn{5}{|c|}{2008} \\
\hline Satisfaction with: & More hours & Same hours & Fewer hours & $\mathrm{N}$ \\
\hline Working conditions & 4.75 & 4.88 & 4.69 & 3759 \\
\hline Financial situation & 3.82 & 4.47 & 4.75 & 3762 \\
\hline Amount of leisure & 4.44 & 4.39 & 3.61 & 3763 \\
\hline Percent (pct.) & 9.02 & 74.17 & 16.81 & 100,00 \\
\hline \multicolumn{5}{|c|}{2001} \\
\hline Satisfaction with: & More hours & Same hours & Fewer hours & $\mathrm{N}$ \\
\hline Working conditions & 4.59 & 4.9 & 4.75 & 1375 \\
\hline Financial situation & 3.67 & 4.58 & 4.81 & 1375 \\
\hline Amount of leisure & 4.73 & 4.57 & 3.58 & 1375 \\
\hline Percent (pct.) & 12.07 & 67.42 & 20.51 & 100,00 \\
\hline
\end{tabular}

Satisfaction ranges 1-6 for all domains with 0 as the least and 6 as the most satisfying.

An interesting question is whether changes in work tensions have an impact on satisfaction with working conditions in 2001 and 2008/09, i.e., whether going from imbalanced working hours - preferences and actual working hours are not in accordance with each other - to balanced working hours entails satisfaction with working conditions. This then leads to the question of whether the opposite movement, from balanced to imbalanced working hours, means less satisfaction with working conditions.

Table 8 shows that only the second change has the expected impact on working conditions: satisfaction with working conditions is reduced when the balance becomes imbalanced, and only on a 10 percent significance level. When dividing the sample into men and women, this relationship keeps its magnitude (same size of coefficients), but the significance disappears, probably because of the smaller sample sizes. By moving from imbalanced to balanced working hours, the coefficients become positive but remain far from being significant. However, if the number of working hours in the 
period remains unsatisfactory, there is a positive correlation with change in satisfaction with the working hours: men become more satisfied and women less satisfied. This difference between men and women is possibly because being over-employed is more disappointing than being under-employed (Reynolds \& Aletraris, 2006) and more women wanted to work fewer hours in 2008 than in 2001 (86 vs. 80 pct.), whereas this number was virtually unchanged for men (76 vs. 74 pct.).

Table 8

Working conditions and work hour tensions. OLS estimations

$\Delta$ Satisfaction with working conditions ${ }^{1}$

2001-2008

\begin{tabular}{|c|c|c|c|}
\hline & All & Men & Women \\
\hline \multicolumn{4}{|l|}{ Work tension: } \\
\hline Balance/imbalance & $-0.231+(0.143)$ & $-0.278(0.182)$ & $-0.186(0.224)$ \\
\hline Imbalance/balance & $0.074(0.129)$ & $0.102(0.166)$ & $0.019(0.201)$ \\
\hline Imbalance/Imbalance & $-0.030(0.174)$ & $0.526 *(0.231)$ & $-0.575 *(0.268)$ \\
\hline \multicolumn{4}{|l|}{ Flexible working time: } \\
\hline 2001 not 2008 & $-0.240(0.166)$ & $-0.250(0.233)$ & $-0.178(0.242)$ \\
\hline 2008 not 2001 & $0.148(0.131)$ & $0.241(0.167)$ & $0.114(0.209)$ \\
\hline \multicolumn{4}{|l|}{ Secondary job: } \\
\hline 2001 not 2008 & $0.375 *(0.167)$ & $0.306(0.202)$ & $0.456(0.288)$ \\
\hline 2008 not 2001 & $-0.061(0.243)$ & $0.0283(0.167)$ & $-0.240(0.467)$ \\
\hline $\mathrm{N}$ & 755 & 410 & 345 \\
\hline Adj. $\mathrm{R}^{2}$ & 0.022 & 0.029 & 0.015 \\
\hline
\end{tabular}

${ }^{1}$ Numerical variable -4 to 4 , mean value 0.027 (0.051)

Controls: age, age*age, marriage, child, educ., see variables in Table 7 
Surprisingly, there is no correlation between having or losing a flexible working arrangement and the satisfaction with working conditions; this holds for both men and women. Losing a secondary job increases satisfaction with working conditions, albeit this increase is netted out when looking at women and men separately (Table 8). Conversely, having a secondary job does not impact satisfaction with working conditions and this also holds when distinguishing between men and women.

\section{Preferred and actual working hours - a macro perspective}

The work tension balance is not only of importance for an individual's welfare, the implication for society is also very relevant. A shortage of labor supply at a societal level due to demographic developments, or a surplus of labor in periods of recession with substantial unemployment are both economic policy issues often referred to in the political debate.

By comparing the number of hours, people wanting to work more hours with those wanting to work fewer hours, no difference shows in either 2001 or 2008/09. For both groups the work tension amounts to a wish for 8 hours more or less work a week. Because the two groups are different sizes, the work tension can be calculated as equal to 7 percent of the total labor supply in 2001 and 6 percent in 2008/09. This implies that the net imbalances are fairly small with a net deficit of labor supply in both years or equal to nearly $30 \mathrm{~min}$ in 2008/09 and $45 \mathrm{~min}$ in 2001 for the quarter of the labor force that was either over- or underworked in the two years.

Transforming the number of weekly working hour tensions calculated above into fulltime working persons, results in there being a labor supply surplus equal to 20,100 employed people in 2001 and 25,600 in 2008/09. Accordingly, the number of underemployed individuals in 2001 was equal to 2.8 percent of those employed at that time and to 2.4 percent in 2008/09, while the equivalent number of over-employed individuals was 3.5 percent and 3.3 percent in 2001 and 2008/09, respectively.

For Germany the tension calculated for the year 2004 based on GSOEP is equal to 2.4 million new jobs - employment deficit - at 34.5 weekly work hours because 
underworked person’s outnumbers overworked persons’ desired working hours (Grözinger et al., 2008).

Figure 2

The macro-balance - under-, over-employed and employment surplus

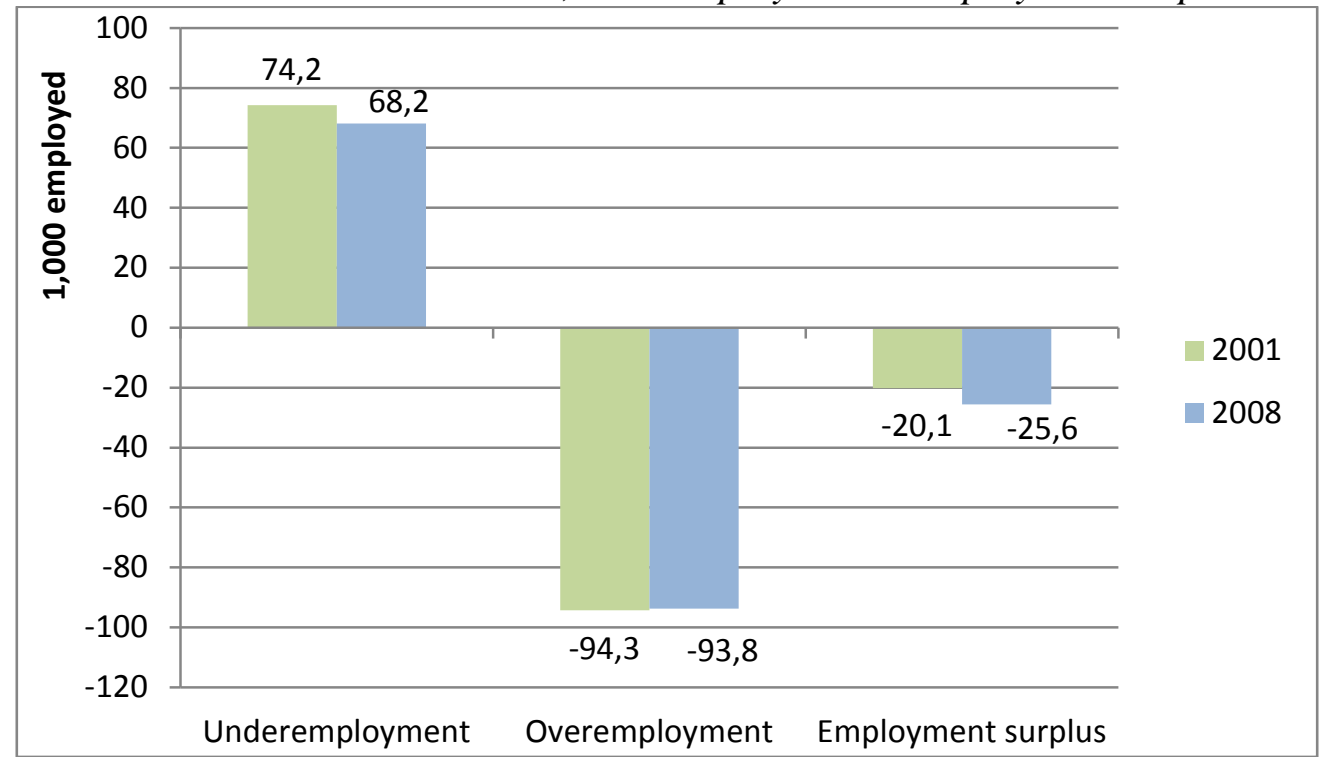

Grözinger et al. (2008) also show that the work tension in Germany implies that job satisfaction, life satisfaction and health satisfaction are considerably smaller than if no tension were present; the same is found for Australia using the Household, Income and Labour Dynamics (HILDA) (Wooden et al., 2009), because over-employment and under-employment have negative impacts on quality of life. Accordingly, high unemployment rates result in people working more unpaid hours than in growth periods because it increases the chances of better job opportunities and higher earnings in the future.

\section{$9 \quad$ Conclusion}

The number of individuals' working hours relatively to the preferred number of working hours - the work tension - is important for the population's wellbeing. Hence, negative working tensions - the number of preferred working hours is lower than the actual working hours - may imply the feeling of being overworked and an unsatisfactory life 
situation with productivity losses as a possible consequence, while positive working tensions - the number of preferred working hours is higher than the actual working hours - may also be unsatisfactory, although it may imply productivity gains due to motivation for advancement and a desire for high incomes.

At the societal level, demographic changes with more elderly people may call for increases in labor supply, either by raising the retirement age or by increasing weekly working hours, the latter necessitating introducing policies amid at decreasing work tensions in the population.

Based on questions about preferences for working hours and actual working hours obtained from the Danish Time-Use Panel Survey 2001-2008/09 (DTUP), where the 2001 wave and the 2008/09 wave were both drawn randomly for the two years from administrative registers by Statistics Denmark, we find that for most Danish people the preferences for work time are in accordance with their actual working hours: 3 out of 4 employed people were satisfied with their actual working hours for the year 2008/09, while only 2 out of 3 had that privilege in 2001. Among those not satisfied with their working hours, 50 percent more wanted to reduce the number of working hours relative to those wanting to increase these hours. In 2001, 21 per cent wanted to work more hours; in 2008/09 this was 16 percent, whereas the percentage of people wanting to work more hours was only 11 for the two years.

We also found that work tensions were correlated with the number of working hours, not only the individual's own but also his/her partner's working time. Hence, if the wife has a part time job, it is less likely that her husband wants to work more hours than if she works the standard 37 hours a week, but if the husband works more than the standard number of hours, the wife is less likely to wish to work more hours a week. This indicates that in the first case there seems to be some synchronization process in play, while in the second case some specialization, with a career man and a homeoriented woman, characterizes the household.

The preferences for working time were satisfied for nearly half of those employed during 2001-2008/09, and 7 percent maintained a desire to work fewer hours and 1 percent to work 
more hours per week. The remaining 37 percent changed their working hour preferences during the period.

An important question addressed in this paper is whether work tensions disappeared due to changes in working hours over the period 2001-2008/09. For those able to fulfill their preferences for working fewer hours in 2001 and, hence, becoming satisfied with working hours in 2008/09, they actually reduced their working time by $4 \frac{1}{4} 4$ hours per week in that period. For those wanting to work more hours and becoming satisfied with their working hours, their working time increased by $4 \frac{1}{2} 2$ hours per week. However, taking changes in working hours into consideration, we show that being underworked in 2001 has a negative impact in 2008/09 on the desire to work fewer hours - being overworked. For those being overworked in 2001, there was a positive impact on the number of people wanting to work fewer hours and a negative impact on those wanting to work more hours in 2008/09. This indicates that for underemployed individuals, controlling for working hour changes implies a higher work tension balance, while this is only partially the case for over-employed individuals some of whom contribute to accentuating the desire to work fewer hours and others contribute to decreasing the desire to work more hours a week.

An interesting question is whether changes in work tensions have an impact on satisfaction with working conditions in 2001 and 2008/09, i.e., does going from imbalanced working hours to balanced working hours - preferences and actual working hours are in accordance with each other - entail satisfaction with working conditions? Further, does the opposite movement from balanced to imbalanced working hours mean less satisfaction with working conditions? Only the second change has the expected impact on working conditions: satisfaction is reduced when balance turns to imbalance, and only on a 10 percent significance level. When moving from imbalanced to balanced working hours, the coefficients are positive but far from being significant. However, if the number of working hours in the period remained unsatisfactory, there was a positive correlation with change in satisfaction with the working hours as men became more satisfied and women less satisfied. 
By comparing the number of hours, people wanting to work more hours with those wanting to work fewer hours, there was no difference in either 2001 or 2008/09. Because the two groups are different in size, the net imbalances are fairly small with a net deficit of labor supply in both years or equal to nearly $30 \mathrm{~min}$ in 2008/09 and $45 \mathrm{~min}$ in 2001 for the quarter of the labor force that was either over- or under-worked in the two years.

By transforming the number of weekly working hour tensions calculated above into full-time working persons, the result shows that there was a labor supply surplus equal to 20,100 employed people in 2001 and 25,600 in 2008/09. This means that the number of under-employed individuals in 2001 was equal to 2.8 percent of the individuals employed at that time and it was 2.4 in 2008/09, while the equivalent numbers of individuals over-employed were 3.5 and 3.3 in 2001 and 2008/09, respectively. From a political viewpoint, this shows that a considerable number of working hours are not in accordance with the preferences of Danish workers, therefore implying a welfare loss. 


\section{References}

Andersen, T. (2012). A Flexicurity Labour Market in the Great Recession: The Case of Denmark. De Economist. Vol. 160, No. 2: 117-140.

Baaijens, C. \& Schippers, J. (2007). The unfulfilled preference for working fewer hours in the Netherlands. In. Labour Transitions and Time Adjustments over the Life Course. Anxo, DD. Dutch University Press. The Netherlands.

Bonke, J. (2014). Normal and actual working hours - why are they different? Working Paper. Rockwool Foundation Research Unit (forthcoming).

Bonke, J., Deding, M. \& Lausten, M. (2009). TIME AND MONEY - A simultaneous analysis of men's and women's domain satisfactions. Journal of Happiness Studies. 2009, vol. 10(2), pp. 113-131.

Böheim, R. \& Taylor, M.P. (2004). Actual and Preferred Working Hours. British Journal of Industrial Relations. 42/1, pp. 149-166.

Beshears, J. Choi, J.J., Laibson, D. \& Madrian. B.C. (2000). How are Preferences Revealed? Working Paper 13976. National Bureau of Economic Research.

Blundell, R. \& MaCurdy, T. (1999). Labor supply: a review of alternative approaches. In: O.C. Ashenfelter \& Card, D. (eds.), Handbook of Labor Economics, vol 3A, North-Holland: Amsterdam.

Clark, A.E. (1996). Job satisfaction in Britain. British Journal of Industrial Relations, 34, pp. 189-217.

Golden, L. \& Gebreselassie, T. (2007). Overemployment mismatches: the preference for fewer work hours. Monthly Labor Review. April 2007: 18-37. 
Clarkberg, M. \& Moen, P. (2001). Understanding the time Squeeze: Married Couples Preferred and actual Work-Hour Strategies. American Behaviour Scientist. 44, 111536.

Drago, R., Wooden, M. \& Black. D. (2006). Who Wants Flexibility? Changing Work Hours Preferences and Life Events. IZA DP No. 2404.

Drago, R., Tseng, Y-P \& Wooden, M. (2005). Usual and Preferred Working Hours in Couple Households. Journal of Family Studies. 11, 46-61.

Golden, L. \& Gebreselaissie, T. (2007). Overemployment mismatches: the preference for fewer work hours. Monthly Labor Review. 18-37.

Grözinger, G., Matiaske, W. \& Tobsch, V. (2008). Arbeitszeitwünsche, Arbeitslosigkeit und Arbeitszeitpolitik, WSI Mitteilungen (2), pp. 92-98.

Jacobs, J.A. \& Gerson, K. (2004). The Time Divide: Work, Family, and Gender Inequality. Cambridge, MA: Harvard University Press.

Hakim, C. (2005). Work-Lifestyle Choices in the $21^{\text {st }}$ Century: Preference Theory. Oxford University Press, New York.

Klevmarken, N.A. (2005). Estimates of a Labor Supply Function. In: Hamermesh, D. \& Pfann, G.A. (eds), The Economics of Time Use. Elsevier. Oxford.

Merz, J. (2002). Time and Economic Well-being - A Panel Analyses of Desired Versus Actual Working Hours. Review of Income and Wealth. Series 48. Number 3: 317346.

Otterbach, S. (2010). Mismatches Between Actual and Preferred Work Time: Empirical Evidence of Hours Constraints in 21 Countries. Journal of Consumer Policy. 33: 143-161. 
Reynolds, J. (2004). When Too Much Is Not Enough: actual and Prweferred Work Hours in the United States and Abroad. Sociological Forum. 19/1. 89-120.

Schor, J.B. (1991). The Overworked American: The Unexpected Decline of Leisure. New York: Basic Books.

Sousa-Poza, A. \& Henneberger, F. (2002): An Empirical Analysis of Working-hours Constraints in Twenty-one Countries, Review of Social Economy, 60 (2), pp. 209242.

Steward, M.B. \& Swafield, J.K. (1997). Constraints on the Desired Hours of Work of British Men. The Economic Journal. 1007/4451, 520-535.

Stier, H. \& Lewin-Epstein, N. (2003). Time to Work: A Comparative Analysis of Preferences for Working Hours. Work and Occupations. Vol. 30 No. 3: 302-326.

Townsend, B. (2001). Dual-earner Couples and Long Work Hours: A Structural and Life Course Perspective. Berkeley Journal of Sociology. SLB, 161-79.

Yerkes, M. (2004). Actual versus Preferred Working Times in the Netherlands: Parttime Patterns or Preferences? Amsterdam School for Social Science Research. The Netherlands.

Wanrooy van, B. (2005). Adapting to the Lifecourse? Evaluating Men and Women's Working-Time Preferences. Australian Journal of Labour Economics. Vol. 8, No. 2: 145-162. 